followed the manufacturing and mining and alimentary industries established in Senegal and several West African and African countries.

In Senegal, the evolution of occupational Health and OHS can be represented into four steps. The first one called the colonial experience, took place before the independences in 1960. The second step, which goes from 1960 to 1987, can be considered like the neocolonial one as the new national authorities have entirely copied the overseas legal provisions in the labour code of 1960. The third step 1988 to 2012, has allowed genuinely the development of Occupational Health and OHS according to ILO normative basis. And finally, the last step 2013 to 2017 has given many opportunities and future priorities in developing $\mathrm{OH}$ and $\mathrm{OHS}$ through a five year action plan 2017-2021 of the national program of safety and health, which has retained four priorities among which the implementation of OHS for $80 \%$ of all enterprises.

\section{9i HOW OHS CAN IMPLEMENT WHAT WE KNOW (OR STILL DON'T KNOW) ABOUT EFFECTIVENESS OF PREVENTIVE INTERVENTIONS AND BECOME EFFECTIVE OHS}

JH Ruotsalainen, JHAM Verbeek. Cochrane Work, Finnish Institute of Occupational Health, Kuopio, Finland

\subsection{6/oemed-2018-ICOHabstracts.645}

When considering the effectiveness of occupational health services (OHS), it is best to think of it as a specific package of interventions. Whether the OHS is effective or not then depends on the availability of effective interventions. By intervention we mean purposefully induced changes in the work environment, in worker behaviour or in a (patho)-physiological function. The effectiveness of interventions results from evaluation by means of controlled experimental studies and by systematic reviews that pull together all these studies and synthesise their results.

The solution for bridging the apparent gulf between scientific evidence and occupational health practice is to employ the PICO acronym. The letters spell out the problem identified in OHS thus: $\mathrm{p}=$ Participants, I=Intervention(s), $\mathrm{C}=$ Control and $\mathrm{O}=$ Outcome(s). For example, is it possible to reduce noise exposure $(\mathrm{O})$ by giving instruction on how to use ear plugs (I) to workers (P) compared to using the devices without the instruction $(\mathrm{C})$ ?

Based on a recently updated Cochrane review, the answer is that there is moderate-quality evidence that with instructions for insertion, the attenuation of noise by earplugs is $8.59 \mathrm{~dB}$ better (95\% CI: $6.92 \mathrm{~dB}$ to $10.25 \mathrm{~dB}$ ) compared to no instruction (2 RCTs, 140 participants). Similarly, we know that one cannot prevent back pain by teaching workers to use a supposedly correct lifting technique. We also know that many OHS do not provide ear plug instruction but do provide correct lifting instructions. For hearing loss and back pain outcomes we know these OHS interventions are not effective.

The use of Cochrane systematic reviews can thus help to show effectiveness of OHS. There are currently more than 140 reviews that are pertinent to occupational health. For each one, the scientific abstract and plain language summary are freely available to everybody everywhere.
1647 ROADMAP ON CARCINOGENS - EU AND NATIONAL INITIATIVES (3RD MAY 2018)

Elke Schneider*. European Agency for Safety and Health at Work, Bilbao, Spain

\subsection{6/oemed-2018-ICOHabstracts.646}

Aim of special session Roadmap on carcinogens - EU and national initiatives (3rd May 2018)

EU-OSHA and its Dutch partners will update the audience about the roadmap's activities and those of the 2018/19 Healthy Workplaces Campaign on dangerous substances. This will be complemented by a report from the workplace level, and the audience will be actively engaged in discussions about future priorities and challenges in this important field of $\mathrm{OSH}$ action.

Laurie Hermans ${ }^{1}$, Wouter Fransman ${ }^{2}$

${ }^{1} \mathrm{TNO}$, Leiden, The Netherlands

${ }^{2}$ TNO, Zeist, The Netherlands

\section{7 a EU-OSHA ACTIVITIES TO COMBAT WORK-RELATED CANCER AND HELP PREVENT EXPOSURE TO CARCINOGENS}

E Schneider. European Agency for Safety and Health at Work, Bilbao, Spain

10.1136/oemed-2018-ICOHabstracts.647

Cancer is considered to be the leading cause of work-related deaths in the EU, with an estimated 120000 new cases and about 80000 deaths per year. It is clear that more can be done to reduce the number of cases of occupational cancer, which is why, on 25 May 2016, EU-OSHA together with five partners signed a covenant committing to a voluntary action scheme to raise awareness of the roadmap for carcinogens 2016-2019. The scheme aims to engage many more organisations, companies and all those concerned in the fight against work-related cancer. EU-OSHA will intensify its efforts to raise awareness of the risks from the exposure to carcinogens at work during its Health Workplaces campaign 2018-2019, which is dedicated to the management of risks from dangerous substances at work. A core task of EU-OSHA is to help share solutions - good practices and initiatives from companies, authorities, labour inspections, trade associations and unions at the national and at the European level. To support the roadmap, EU-OSHA therefore engages with national partners in their activities and provide them with a basic set of tools and instruments to raise awareness of this important topic, including information sheets, case studies, and a database of tools and instruments. EU-OSHA is also committed to organising regular international stock-taking events where best practice examples are presented and progress is discussed from the point of view of all the actors involved in improving prevention. This presentation focuses on a range of activities that help fulfil the common goal of reducing the death toll from exposure to carcinogens to underline the role that every actor can play.

\section{7b THE EUROPEAN ROADMAP ON CARCINOGENS: LET'S GET SMART ABOUT CARCINOGENS AT WORK}

Laurie Hermans. TNO, Leiden, The Netherlands

10.1136/oemed-2018-ICOHabstracts.648 